\title{
Analysis the Effectiveness Internal Control System and Management Morality on Tendency of Fraud in Accounting
}

\author{
Delvia Vamela ${ }^{1}$, Hari Setiyawati ${ }^{2}$ \\ \{delviavamella15@gmail.com¹,hari_setiyawati@mercubuana.ac.id² \\ Mercu Buana University, Jakarta, Indonesia ${ }^{12}$
}

\begin{abstract}
This research begins with the phenomenon of fraud in accounting that has occurred in many countries, where fraud that occurred in Toshiba Corp (Japan) and SNP Finance (Indonesia) has tarnished credibility in accounting practices. This study aims to examine and analyze the significant influence of the effectiveness of the internal control system and the morality of accounting management on the tendency of fraud in accounting. This research is quantitative with a causal approach. The population of this research is the private sector companies in Jakarta and Tangerang. The sample of this research were 60 companies. Data were analyzed using the Second Order Confirmation Equation Model (SEM) structure with the Partial Least Square (PLS) approach. The results showed the effectiveness of the internal control system had no significant effect on the tendency of fraud in accounting. Conversely, Management Morality has a significant effect on the tendency of fraud in accounting.
\end{abstract}

Keywords: Tendency of Fraud in Accounting, Effectiveness of The Internal Control System, Management Morality

\section{Introduction}

Fraud in accounting has occurred in many countries. Japanese Finance Minister, Taro Aso, regretted the fraud case in Japan 2015 that was carried out by Toshiba Corp. because the case occurred at a time when Prime Minister Shinzo Abe was trying to regain the confidence of global investors with better corporate governance guidelines [1]. Based information from www.reuters.com [2]. The independent investigation team found that Toshiba had Toshiba manipulated a profit report from 2008 of $¥ 151.8$ billion, or about US \$ 1.22 billion. Based on data processing from Corruption Perception Index on the chart below, Indonesia is a country that has the lowest Corruption Perception Index score from 2015 2018 compared to neighboring countries. In other words, compared to Singapore, Malaysia and Brunei. Indonesia had the highest corruption cases from 2015-2018.

In Indonesia, fraud in accounting that is enough to steal attention is the biggest fraud in accounting in the financial sector in 2018. quoted from [4] Five directors and managers of PT Sunprima Nusantara Pembuangan (SNP Finance) were secured by the authorities related to the alleged criminal act of document forgery, embezzlement, fraud, and money laundering in their business activities as a multi-finance company. According to [5] Association of Certified Fraud Examiners (ACFE) accounting fraud categorizes fraud into three groups, namely: corruption, asset misappropriation and fraudulent statements, where, fraud in 
financial statements can be defined as fraud committed by management in the form of material misstatement of financial statements that is detrimental to investors and creditors.

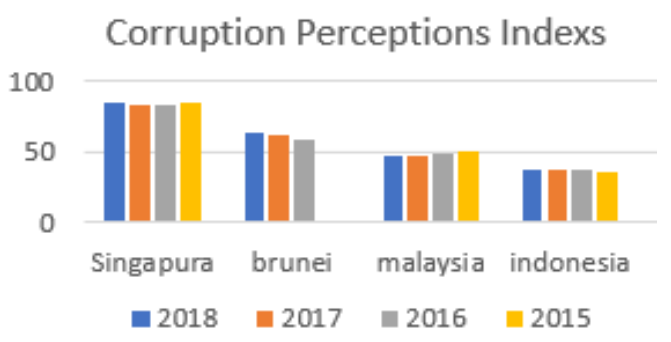

Fig 1. Corruption Perceptions Index's [3]

Research conducted by Handoko 2020 [6] showed that there was a significant influence between internal control and the tendency of fraud. According of Khallawy 2020 [5] in his research, the application of an internal control system can be a safeguard that saves economic unit assets and ensures the correctness of financial reports from errors or manipulation by employees in these institutions, besides, it can motivate employees to comply with the law. Previous research conducted by Wilopo 2006 [7] showed that the higher the level of morality of management in a company, the management tries to avoid the tendency of accounting fraud.

The results of research conducted by Awang 2019 [8] found that subjective attitudes and norms have a positive effect on fraudulent intentions in financial reporting. Another meaning is that more people in an agency support fraud and feel that the group enforces and supports this behavior the stronger their intention to commit fraud. The research aims to examine and analyze: (1) Significant Effect of Effectiveness of the Internal Control System on Tendency of Fraud in Accounting (2) Significant Effect of Management Morality on Tendency of Fraud in Accounting

\begin{abstract}
Agency Theory
According to Jensen and Meckling [9] describes agency relationships as "agency relationships as a contract under which one or more people (the principals) engage another person (the agent) to perform some service on their behalf which involves delegating some decision making authority to the agent". Jensen and Meckling's agency theory [9] often used to explain accounting fraud. Agency theory intends to solve two problems that occur in agency relationships. Problems arising from differences in interests between principals and agents are called agency problems.
\end{abstract}

\title{
Accounting Fraud
}

Arens (2015:396) [10] mentioning Fraud is any dishonesty intentionally to seize the rights or ownership of another person or party. In the context of an audit of financial statements, fraud is defined as intentional misstatement of financial statements. The two main categories of fraud are report fraud and asset misuse where fraud in financial reporting is a misstatement that is committed intentionally with the intention of deceiving or tricking the users of the financial statements. The majority of cases involve reported misstatements compared to disclosures. Elimination of reported amounts is a less common case, but a company can exceed revenue by eliminating trade payables and other liabilities and Misuse 
of assets can be classified as cash fraud and fraud of inventory and other assets, and fraudulent expenses. (fraudulent disbursement). Like taking company money, using an official car for personal use. Arens 2015 [10] mention the three conditions of fraud originating from fraudulent financial reporting and misuse of assets described in SAS 99 (AU 316), these three conditions are referred to as a fraud triangle (Fraud Triangle), namely: 1) Incentives / Pressure, 2) Opportunities, 3) Attitudes or rationalization.

The results of research from [11] found that none of the three factors (pressure, opportunity and rationalization) had a significant effect on fraud. However, when comparing these factors, this pressure is considered to have the highest impact. When it comes to fraud prevention, employees suggest that it is very important to implement all prevention tools, especially those related to adequate segregation of duties.

\section{The Internal Control System}

According to the Committee of Sponsoring Organization Treadway Commission (COSO) [10] "Internal control is defined as a process that is influenced by the board of directors, management and employees that are designed to provide a convincing guarantee that the objectives of the organization will be achieved, adherence to applicable laws". Arens [10] explained that the internal control system consists of policies and procedures designed to provide management with reasonable certainty that the company has achieved its goals and objectives. The internal control system consists of policies and procedures designed to provide management with reasonable certainty that the company has achieved its goals and objectives. These policies and procedures are called controls, and collectively shape the entity's internal controls.

Five Internal control components, namely: 1). Control Environment 2). Risk Assessment 3). Control Activities 4). (Information \& Communication) and 5). Monitoring. In study in conducted by [12] internal control has an effect on fraud, where internal control has a negative influence, which means the better the internal controls implemented in a company, the lower the level of fraud. According to [6] the higher the score control system, the lower the level employee fraud.

\section{Management Morality}

Management morality is management's action to do the right thing and not related to profit or value. In companies, the higher the morality of management, it is expected that of accounting fraud can be avoided [13]. In Kohlberg's theory of moral development (1969)[14] states that morals develop through three stages, namely the pre-conventional stage, the conventional stage, and the post-conventional stage. According to Awang 2019 [8] , the more people in an agency that support fraud and feel that the group approves and supports this behavior, the stronger their tendency to commit fraud.

\section{Framework}

Weak internal control systems and poor management morality within the company can be an opportunity for fraud to prevent or minimize fraud so it is necessary to build a reliable internal control system and instill integrity values. Internal control is built to provide assurance that organizational goals will be achieved through efficiency and effectiveness of operations, presentation of reliable financial statements, and compliance with applicable laws and regulations as stated in terms of control under the COSO (Committee of Sponsoring Organization Treadway Commission ) [10]. 
In Kohlberg's theory of moral development (1969) [14] states management morality at the post-conventional stage shows high moral management maturity. Another opinion of Wilopo said, the higher the level of morality of management in a company, the more management tries to avoid the fraud in accounting the relationship between the Effectiveness of the Internal Control System and Management Morality on the Tendency of Fraud in Accounting can be seen in figure. following:

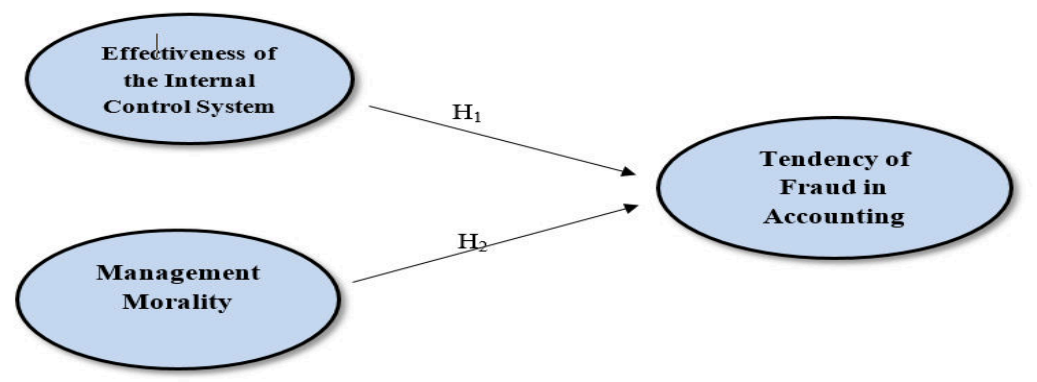

Fig 1. Framework

\section{Hypothesis}

Based on the conceptual framework above, the hypotheses in this study are as follows:

$\mathrm{H}_{1}$ : The Effectiveness of Internal Control Systems Has a Significant Effect on Tendency of Fraud in Accounting

$\mathrm{H}_{2}$ : Management Morality Has a Significant Effect on Tendency of Fraud in Accounting.

\section{Research Method}

The dependent variable in this study is the tendency of fraud in accounting. This variable dimension is Disclosure in financial statements to deceive users of financial statements where the indicator used to measure the Tendency of Fraud in Accounting consists of five question items that refer to research conducted by Wilopo 2006 [7] \& Awang 2019 [8]. The internal control system variable uses 5 dimensions which refer to the 5 components of COSO internal control. These dimensions include 1). Control Environment 2). Risk Assessment 3). Control Activities 4). Information \& Communication and 5). Monitoring The indicators in this study consisted of 12 questions developed from Arens [10] \& Setiyawati, et al [15]. Management Morality Variables in this study use the dimensions of Kohlberg's theory of moral development (1969) [14], The measurement of management morality comes from the moral measurement model in the form of the Defining Issues Test instrument. This instrument takes the form of an ethical dilemma case. consists of 6 indicators as a basis for questions.

The population in this study consisted of private companies in the Jakarta and Tangerang regions. The sample in this study were 60 companies. sampling using sampling based on convenience (Convenience Sampling). The respondents of this study were employees of the accounting or financial department in the company. The interval scale 1-5 is used to measure the response of respondents. The research hypothesis testing was conducted using the Structural Equation Model (SEM) approach. Data analysis using Partial Least Square (PLS) software. There are 2 things done, namely: Assessing the outer model and Assessing the Inner Model. using the PLS Warp program and SEM-PLS Second-Order Construct analysis. 


\section{Results and Discussion}

\subsection{Descriptive Statistics Analysis}

Table 1. presents a description of the average effectiveness of the internal control system variables measured by 5 reflective dimensions, Management Morality measured by 1 reflective dimension and the Tendency of Fraud in Accounting as measured by 1 reflective dimension.

Table 1. Descriptions of the Effectiveness of The Internal Control System, Management Morality, Tendency of Fraud in Accounting Variables

\begin{tabular}{clcc}
\hline No & \multicolumn{1}{c}{ Variables } & Average & Standard Deviation \\
\hline 1 & Effectiveness of The Internal Control & 3,96 & 0,76 \\
& System & 3,41 & 0,92 \\
2 & Management Morality & 3,46 & 0,88 \\
3 & Tendency of Fraud in Accounting & &
\end{tabular}

Source: Processed Primary Data, 2019

Variable Effectiveness of the Internal Control System shows an average value of 3.96 This shows that the company has implemented the Effectiveness of the Internal Control System quite well in matters relating to maintaining the reliability of the presentation of financial statements, operational efficiency and compliance with applicable laws and regulations. The variable morality of management shows an average value of 3.41 . This shows that overall Management Morality in the research object is good enough. With a fairly good management morality this can reduce fraud committed by the leadership of the company. Variable Tendency of Fraud in Accounting Fraud shows an average value of 3.46. This shows that overall, the tendency of fraud in accounting in companies is quite low. However, employees and management must take actions that can prevent fraud in any form.

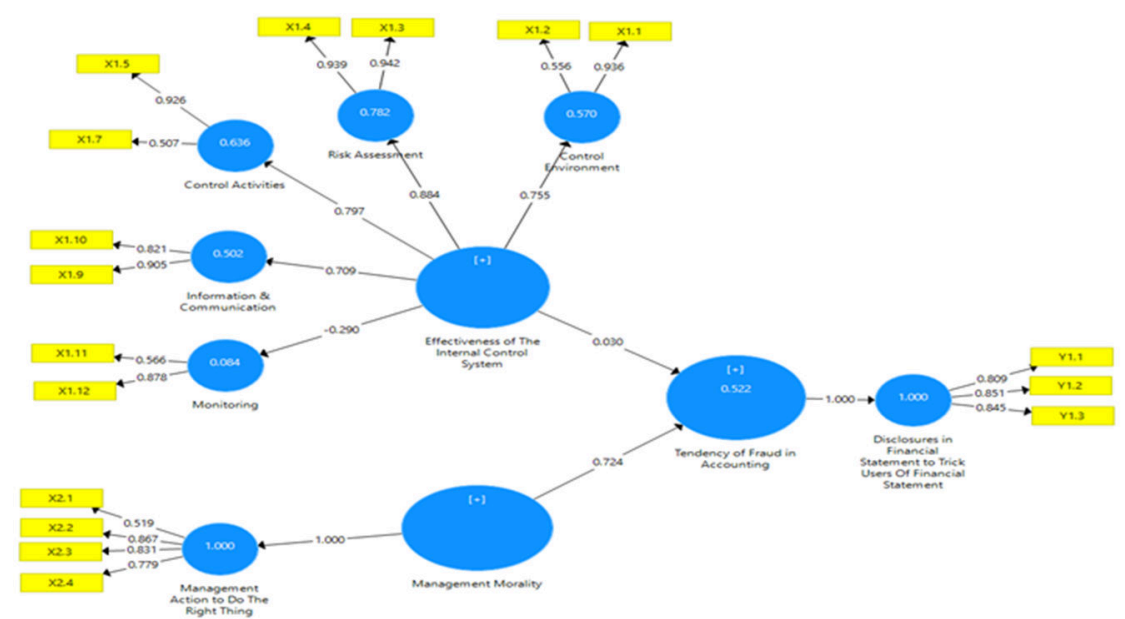

Fig 2. Output Loading 


\subsection{Test of Validity and Reliability (outer model)}

The following figure 2. is the result of the output factor loading construct The Effectiveness of the Internal Control System, Management Morality, and the Tendency of Fraud in Accounting? The results of the loading construct second order factor The Effectiveness of the Internal Control System, Management Morality, and the Tendency of Fraud in Accounting in the Smart PLS have met the convergent validity that is the indicator value is above 0.5 . All loading factors on both the second and first orders are significant at the $5 \%$ level, so the indicators are valid.

Table 2: Reliability Test

\begin{tabular}{|c|c|c|c|c|}
\hline Variable & $\begin{array}{l}\text { Composite } \\
\text { Reliability }\end{array}$ & $\begin{array}{l}\text { Cronbach's } \\
\text { Alpha }\end{array}$ & AVE & Information \\
\hline $\begin{array}{l}\text { Effectiveness of The Internal } \\
\text { Control System }\end{array}$ & 0,876 & 0,828 & 0,546 & Reliable \\
\hline Management Morality & 0,842 & 0,746 & 0,580 & Reliable \\
\hline Tendency of Fraud in Accounting & 0,873 & 0,783 & 0,697 & Reliable \\
\hline
\end{tabular}

Based on table 2, the results of the reliability variables of the Effectiveness of the Internal Control System, Management Morality, and the Tendency of Fraud in Accounting have composite reliability above 0.6 . the indicators used in each variable have good reliability or are able to measure the construct.

\subsection{Evaluation of Goodness of Fit of Structural Models (Inner Model)}

Table 3. R-Squared

\begin{tabular}{lc}
\hline \multicolumn{1}{c}{ Variable } & Rsquare \\
Tendency of Fraud in Accounting & 0,522 \\
Predictive-Relevance $\left(\boldsymbol{Q}^{2}\right)$ & 0,478 \\
\end{tabular}

Based on the coefficient of determination in table 3, the value of the cheating tendency variable in accounting is 0.522 , which means that the value indicates that the effectiveness of the Internal Control System, Management Morality is $52.2 \%$ while the remaining $47.8 \%$ is influenced by other variables not contained in the model research.

\section{Hypothesis test}

Based on the test results above shows the value of Tstatistic of each variable is greater than Ttable This means that the dimensions of each variable are able to measure each construct. To find out the significance of each variable by looking at the value of the parameter coefficient and the significance value of the statistics can be seen in table 4 . as follows:

Table 4: Path Coefficients

\begin{tabular}{lllcll}
\hline \multicolumn{2}{c}{ Inter-variable Relationships } & $\begin{array}{l}\text { Parameter } \\
\text { coefficient }\end{array}$ & $\begin{array}{c}\text { T } \\
\text { Statistic }\end{array}$ & $\begin{array}{c}\text { P } \\
\text { Value }\end{array}$ & Description \\
\hline $\begin{array}{l}\text { Effectiveness of the Internal } \\
\text { Control System } \rightarrow \text { Tendency of }\end{array}$ & 0,030 & 0,306 & 0,760 & $\begin{array}{l}\text { Not } \\
\text { significant }\end{array}$ \\
\hline
\end{tabular}




\begin{tabular}{|c|c|c|c|c|}
\hline Fraud in Accounting & & & & effect \\
\hline $\begin{array}{l}\text { Management Morality } \rightarrow \text { Tendency } \\
\text { of Fraud in Accounting }\end{array}$ & 0,724 & 10,479 & 0,000 & $\begin{array}{l}\text { Significant } \\
\text { effect* }\end{array}$ \\
\hline
\end{tabular}

The following is the inner output model of the smart software PLS Version 3.2.8. Here is a picture that explains the path diagram to test the hypothesis:

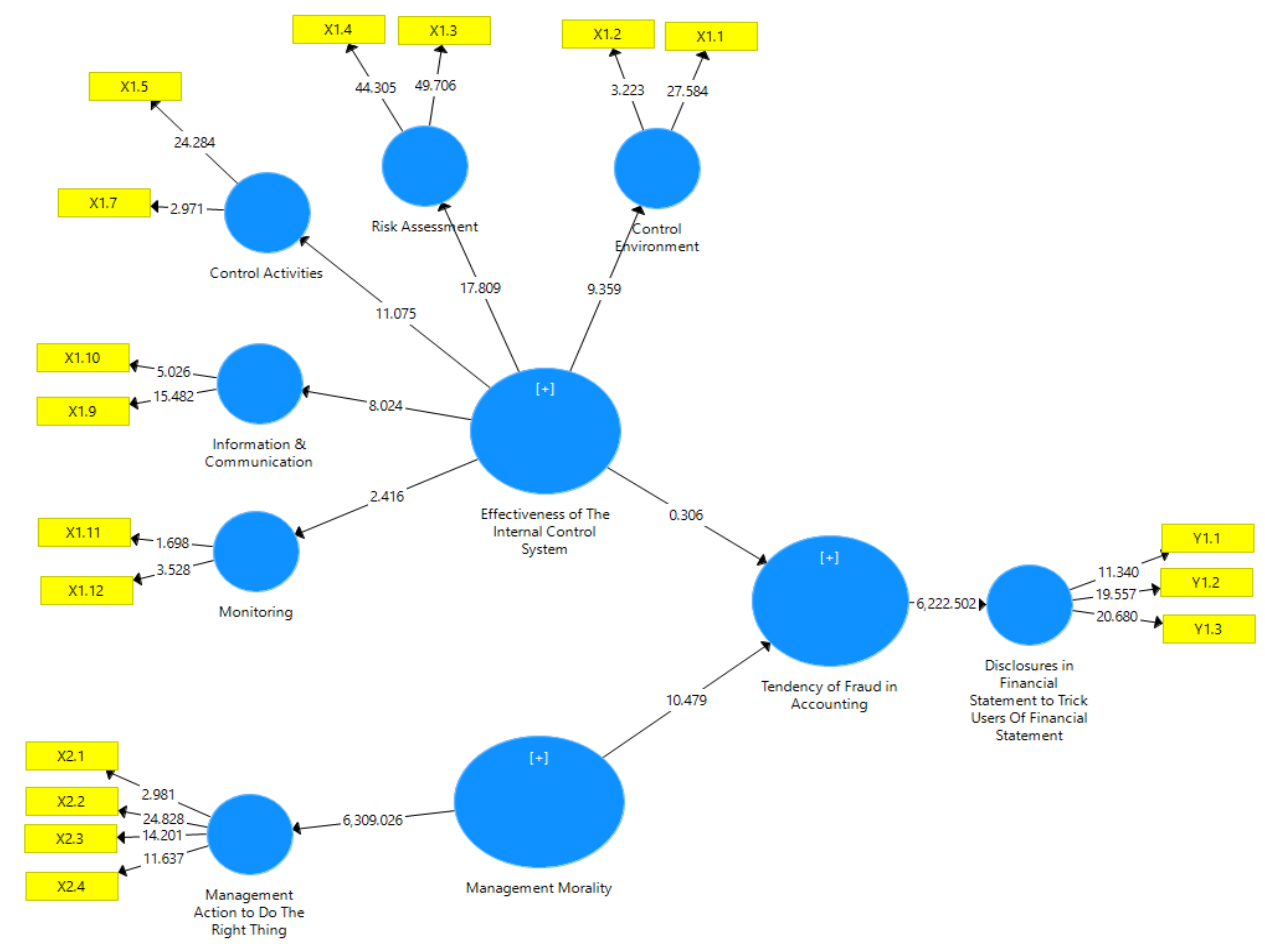

Figure 3. Output Inner Model

Path parameter coefficient obtained from the effect of the variable Internal Control System Effectiveness on Tendency of Fraud in Accounting. is 0.030 with a Tstatistics value of $0.306<1,670$ at a significance level $\alpha=0.05(5 \%)$ which states that there is no significant effect of the Effectiveness of the Internal Control System on Tendency of Fraud in Accounting. Path parameter coefficient obtained from the influence of Management Morality on Tendency of Fraud in Accounting is 0.724 with a Tstatistics value of $10.479>1.670$ at a significance level of $\alpha=0.05(5 \%)$ which states that there is a significant influence of Management Morality on Tendency of Fraud in Accounting. it means that management morality can reduce the level of fraud in accounting.

The effectiveness of the Internal Control System does not significantly influence Tendency of Fraud in Accounting. This illustrates that companies that have been quite good in implementing components of the internal control system have not been able to reduce the tendency of fraud in accounting. Internal control depends on morality. This illustrates the condition exists and no element of internal control does not affect management that has a high moral level to commit accounting fraud. Even though there is no internal management 
control with high morality, there is no interest in accounting fraud. Crowe Horwath, 2012 [16] opinion in Pentagon fraud theory, there are three factors related to internal control that cause accounting fraud, namely competence, arrogance, opportunity. Competence is the ability of employees to ignore internal supervision, develop concealment strategies, and control social situations for personal gain.

Arrogance is the attitude of superiority over the rights held and feels that internal control or company policy does not apply to him. Two components of opportunity, namely general information and technical skills. General information is the knowledge that positions that contain trust can be violated without consequences. The information held forms the belief that because of the position and trust of the institution that is inherent in him, the fraud he committed will not be known. that is, expertise that is owned by someone and that causes someone to get a position. Without adequate ability to hide fraud or corruption, it is certainly not possible especially for systematic cases.

Thus, the pentagon fraud theory can be justified in internal control variables. The results of this study are in line with previous studies conducted Sujand ari dan Mataningtyas [17] and Harry Krishna Mulia 2017 [18] which states that internal control has an effect on fraud. The results of this study are not in line with previous research by Wilopo 2006 [7], Handoko 2020 [6] where the effectiveness of internal control affects the Tendency of Fraud in Accounting. Management Morality has a significant effect on Tendency of Fraud in Accounting. This means that the higher the morality of management in a company, the higher the awareness of management not to commit fraud in accounting. The results of this study are in line with Kohlberg's theory of moral development [14] states that morals develop through three stages, namely the pre-conventional stage, the conventional stage, and the post-conventional stage.

Management morality at the post-conventional stage shows the high moral maturity of management. The results of this study are in line with previous research conducted by Wilopo [7] which explains the higher level of management morality in a company, the more management tries to avoid the Tendency of Fraud in Accounting. The results of this study are also in line with research from Awang 2019 [8] which shows results more people in an agency support fraud and feel that the group enforces and supports this behavior the stronger their intention to commit fraud. The results of this study are not in line with the results of previous studies conducted by Alou, et al [19] Management Morality does not have an influence on Tendency of Fraud in Accounting.

\section{Conclusion}

The effectiveness of the Internal Control System does not significantly influence the tendency of fraud in accounting. Management Morality has a significant effect on the Tendency of Fraud in Accounting. It is recommended that private companies in the Jakarta \& Tangerang area maintain and enhance the morality of individual employees and management. In addition, for further development in an effort to stop fraud in accounting, the company should supervise the control system in the company, not only continuously, but also needs to be reviewed on an ongoing level of effectiveness. effectiveness of internal control in order to minimize the tendency of fraud in accounting. 


\section{References}

[1] I. L. Hakim, "Skandal Terungkap, CEO Toshiba Mundur," Liputan 6 Web : https://www.liputan6.com/bisnis/read/2277114/skandal-terungkap-ceo-toshiba-mundur, 2015.

[2] Ritsuko Ando, "Toshiba scandal continues as more accounting errors found," https://www.reuters.com/article/us-toshiba-results-idUSKCN0R00SX20150831, 2015.

[3] Transpararency International, “'Corruptiom Perceptions Index 2015,"” Transpararency International web https://www.transparency.org/cpi2018, 2018. .

[4] C. I. Tim, "Kronologi SNP Finance dari 'Tukang Kredit' ke 'Tukang Bobol," www.cnnindonesia.com, 2018.

[5] ACFE, "Report to the Nations 2018 Global Study on Occupational Fraud and Abuse," 2019.

[6] B. L. Handoko, R. O. Wijaya, and A. Azhary, "The Influence of Economic Pressure , Internal Control , and Organizational Culture to Tendency of Fraud," Test Eng. Manag. J., vol. 83, no. 18173, pp. 18173-18182, 2020, [Online]. Available: http://testmagzine.biz/index.php/testmagzine/article/view/6947/5355.

[7] Wilopo, "Analysis of Factors Affecting the Tendency of Accounting Fraud: A Study on Public Companies and State Owned Enterprises in Indonesia," Indones. J. Account. Res., vol. 9, no. 3, 2006, doi: http://doi.org/10.33312/ijar.163.

[8] Y. Awang, "The influences of attitude, subjective norm and adherence to Islamic professional ethics on fraud intention in financial reporting," J. Islam. Account. Bus. Res., vol. 10, no. 5, pp. 710-725, 2019, doi: 10.1108/JIABR-07-2016-0085.

[9] M. Jensen and W. H. Meckling, "Theory of the firm: Managerial behavior, agency costs and ownership structure,” J. financ. econ., vol. 3, no. 4, pp. 305-360, 1976, [Online]. Available: https://econpapers.repec.org/RePEc:eee:jfinec:v:3:y:1976:i:4:p:305-360.

[10] Arens A. Alvin. Ellder J. Ronald \& Beasley Mark S, Auditing dan Jasa Assurance Pendekatan Terintegrasi. Jakarta: Erlangga, 2015.

[11] A. J. Rizky and A. Desi, "Fraud risk factors and tendency to commit fraud: analysis of employees' perceptions,” Int. J. Ethics Syst., vol. 35, no. 4, pp. 545-557, Jan. 2019, doi: 10.1108/IJOES-03-2019-0057.

[12] N. Anuar and S. A. S. A. Puteh, "Internal control and employees' occupational fraud on expenditure claims," J. Financ. Crime, vol. 25, no. 3, pp. 891-906, Jan. 2018, doi: 10.1108/JFC-07-2017-0067.

[13] N. R. Baron, Robert A. \& Branscombe, "Social psychology," Amerika: Harlow: Pearson Education., 2017.

[14] J. I. M. Carpendale, "Kohlberg and Piaget on Stages and Moral Reasoning," Dev. Rev., vol. 20, no. 2, pp. 181-205, 2000, doi: 10.1006/drev.1999.0500.

[15] H. Setiyawati, R. Mappanyuki, M. King, and Suryanih, "Chievementof Auditor Opinion through Application of Government Accounting Standards and Effectiveness ofthe Internal Control System,” Am. J. Humanit. Soc. Sci. Res., vol. 3, no. 9, pp. 90-101, 2019.

[16] Crowe Horwath, "The Mind Behind The Fraudsters Crime: Key Behavioral and Environmental Elements," Crowe Horwath LLP, pp. 1-62, 2012, [Online]. Available: www.crowe.com.

[17] D. A. Surjandari and I. Martaningtyas, "An Empirical Study: The Effect of Performance Incentives, Internal Control System, Organizational Culture, on Fraud of Indonesia Government Officer," Mediterr. J. Soc. Sci., vol. 6, no. 5, pp. 71-76, 2015, doi: 10.5901/mjss.2015.v6n5s5p71.

[18] M. Harry Krishna Mulia, R. Febrianto, and R. Kartika, "Pengaruh Moralitas Individu dan Pengendalian Internal terhadap Kecurangan: Sebuah Studi Eksperimental," J. Account. invesment, vol. 18, no. 2, pp. 198-208, 2017, doi: 10.18196/jai.180283.

[19] S. D. Alou, V. Ilat, and H. Gamaliel, "The Effect of Compensation Suitability, Management Morality, and Effectiveness of Internal Controls on the Tendency of Accounting Fraud in Construction Companies in Manado," Going Concern J. Ris. Akunt., vol. 12, no. 01, pp. 139148, 2017, doi: 10.32400/gc.12.01.17146.2017. 